\title{
Ohio Fall
}

Becky Gross

Cedarville University

Follow this and additional works at: https://digitalcommons.cedarville.edu/cedarvillereview

Part of the Art and Design Commons, Fiction Commons, Nonfiction Commons, and the Photography Commons

DigitalCommons@Cedarville provides a publication platform for fully open access journals, which means that all articles are available on the Internet to all users immediately upon publication. However, the opinions and sentiments expressed by the authors of articles published in our journals do not necessarily indicate the endorsement or reflect the views of DigitalCommons@Cedarville, the Centennial Library, or Cedarville University and its employees. The authors are solely responsible for the content of their work. Please address questions to dc@cedarville.edu.

\section{Recommended Citation}

Gross, Becky (2004) "Ohio Fall," Cedarville Review. Vol. 7, Article 1.

Available at: https://digitalcommons.cedarville.edu/cedarvillereview/vol7/iss1/1 


\section{Ohio Fall}

\section{Keywords}

Cedarville Review, poetry, Ohio, Autumn, Fall

Creative Commons License

(c) (i) (9)

This work is licensed under a Creative Commons Attribution-Noncommercial-No Derivative Works 4.0 License. 


\section{Becky Gross}

\section{Ohio Fall}

Hills grazing - pregnant of bones, fall leaves, and

Katherine Anne's chunk of dead rock leaning against that tree. I

sit beside her soaking in the sunlight while nearby someone else is drowning even deeper beneath the surface. The

sinker asks me to introduce Katherine, but

I'm not the one who knows her: maybe the nearby little lamb guarding

atop a stone the name fading in lichen. I walk through the beautiful debris death has left me. No, not "me."

\section{Revival Meeting}

Ancient cords snapped during

“O For a Thousand Tongues,"

animating the strays into

various snickers and glances.

They had completely faded from inhaling the pastel shirts plastered "Naughty:"

Organs tumbled from the platform but an infant recovering the stage sported

“God can rock your world."

Applause buried the pipes beneath hymnals. 